\title{
Morphology and biology of parasite responsible for scuticociliatosis of cultured olive flounder Paralichthys olivaceus
}

\author{
Bo-Young Jee*, Yi-Cheung Kim, Mi Seon Park
}

Pathology Division, National Fisheries Research and Development Institute, 408-1, Kijang, Pusan 619-900, Korea

\begin{abstract}
Based on the arrangement and shape of the buccal structure, scuticociliates isolated from cultured olive flounder Paralichthys olivaceus belonged to the family Uronematidae and showed many characteristics of Uronema marinum. There was variation in the morphometry of clinical isolates taken from different organs of infected flounder. However, the isolates did not show any significant difference in morphometry under cultured conditions. The ciliates were easily maintained in in vitro medium to which antibiotic agents had been added and which had been enriched with the raw brain tissue of a healthy olive flounder. The ciliates propagated in a wide range of both temperature $\left(6\right.$ to $\left.30^{\circ} \mathrm{C}\right)$ and salinity $(10$ to $35 \mathrm{ppt})$.
\end{abstract}

KEY WORDS: Olive flounder · Paralichthys olivaceus $\cdot$ Scuticociliatosis $\cdot$ Uronema marinum

\section{INTRODUCTION}

Recently, scuticociliates have been recognized as being a serious pathogen in worldwide mariculture. Problems caused by these ciliates have beenn highlighted by reports of mass mortalities in both juvenile flounder Paralichthys olivaceus and turbot Scopthalmus maximus, adult sea bass Dicentrarchus labrax, and subadult southern bluefin tuna Thunnus maccoyii (Yoshinaga \& Nakazoe 1993, Dykova \& Figueras 1994, Dragesco et al. 1995, Munday et al. 1997). The farming of olive flounder $P$. olivaceus, which has become an important marine fish in land-based tank facilities, has been widespread in Korea. One problem associated with flounder farming in Korea is scuticociliatosis. Not only mass mortalities of fry but also high cumulative moralities of juveniles caused by infection with ciliates have occurred frequently in many farms (B.-Y. Jee pers. comm.). Ototake \& Matsusato (1986) recorded scuticociliatosis in cultured flounder for the first time. They suggested that the causative organism is a facultative parasite, opportunistically invading fish seriously stressed under unfavorable environments.

*E-mail: protjee@nfrdi.re.kr
Although the culture characteristics of the ciliates, including optimal cultivation conditions, have been well established (Yoshinaga \& Nakazoe 1993, 1997), little is known about the morphology or biology of the ciliate. In this paper we isolated the ciliate from infected flounder and described its morphological and biological characteristics to compare the present ciliates with other known scuticociliates.

\section{MATERIALS AND METHODS}

Fish. Scuticociliate-infected fish (body length: 10 to $20 \mathrm{~cm} ; \mathrm{n}=30$ ) were obtained from a local land-based flounder farm, located in Kijang, Pusan, Korea, where the infection rate of scuticociliates was $100 \%$, estimated by the presence of the ciliate in wet mounts $(\times 100)$. Tissue samples fixed in $10 \%$ neutral formalin were embedded routinely in paraffin, before sectioning at $5 \mu \mathrm{m}$ and staining with protein silver solution using the Bodian method.

Morphology of ciliates. Clinical isolates were prepared for wet mounts of both brain and skin tissues of infected fish using normal saline. Cultured ciliates were prepared as follows: The whole tissues of the 
infected brain were put into $3 \mathrm{ml}$ of normal saline in a tissue culture dish $(35 \times 10 \mathrm{~mm}$, Corning $)$ at room temperature. One $\mathrm{ml}$ of infected culture medium (with $10 \mathrm{ml}$ of saline) was transferred into a $25 \mathrm{~cm}^{2}$ tissue culture flask (Corning) at $17^{\circ} \mathrm{C}$. The saline medium consisted of a $0.85 \%$ sterile physiological saline solution containing $0.1 \%$ antibiotic (penicillin-streptomycin, Sigma). The whole brain tissue of a healthy flounder (juvenile, avg $15 \mathrm{~cm}$ ), in a raw state, was washed several times and added to the cultures, as food for ciliates. Ciliates were subpassaged $(1 \mathrm{ml}$ of infected culture medium was inoculated into $10 \mathrm{ml}$ of fresh medium prepared as above), every 7 to $10 \mathrm{~d}$. Cultures were maintained at $17 \pm 1^{\circ} \mathrm{C}$. Each clinical isolate was examined unstained to record vital characteristics. Cultured ciliates were fixed in formalin or Bouin's fluid, washed in distilled water and subsequently stained with Giemsa solution or by silver nitrate impregnation using standard techniques (Klein 1958, Foissner 1991). Stained or unstained ciliates were examined under a light microscope, and their sizes were measured using an ocular micrometer. For scanning electron microscopy, cultured ciliates were fixed in an equal volume of fixative (5\% glutaraldehyde, 1 volume $+0.2 \mathrm{M}$ sodium cacodylate, 1 volume) and washed with $0.2 \mathrm{M}$ sodium cacodylate buffer, $\mathrm{pH} 7.4$ at $4^{\circ} \mathrm{C}$, followed by a post-fixative in $2 \%$ aqueous osmium tetroxide for $20 \mathrm{~min}$. The specimens were placed on a fine mesh $(10 \mu \mathrm{m})$ made of Nitex nylon netting, dehydrated in a graded ethanol series, criticalpoint-dried, and examined with a Jeol JSM-35 scanning eletron microscope.

Biology of ciliates. The effects of temperature and salinity on viability and reproductive ability were investigated to estimate the biological characteristics of the ciliate. $0.1 \mathrm{ml}$ of cultures $\left(<10^{3}\right.$ cell ml $\left.\mathrm{m}^{-1}\right)$ were inoculated into $10 \mathrm{ml}$ of fresh medium in $25 \mathrm{~cm}^{2}$ tissue culture plates containing juvenile flounder brain tissue as mentioned above, and then incubated at different temperatures $\left(6\right.$ to $36^{\circ} \mathrm{C}$ ) and salinities (5 to $50 \mathrm{ppt}$ ). To define whether temperature and salinity influence the ciliates, motility response was observed daily under a phase-contrast microscope, and growth response, estimated by the cell number, was checked at regular intervals during experimental periods.

\section{RESULTS}

\section{Pathological and parasitological finding}

Both the epidermal and dermal layers of the skin were severely narcotized, concomitant with the invasion of the ciliates. Many erythrocytes phagocytised by the ciliates were seen and a number of macrophages had accumulated. A number of ciliates were seen between dermis, causing extensive sloughing of the epidermis (Fig. 1a). In heavily infected fish, masses of ciliates were found to feed on host tissue within internal organs such as the muscles, gills, brain and kidney, causing dystrophic changes and necrosis. In some sections the ciliates were seen dividing (Fig. 1c).

The parasite removed from the infected fish was ovoid in shape and opaque, whereas the cultured ciliate was more slender and transparent. The ciliate was uniformly covered with short somatic cilia and possessed a prominent caudal cilium, which had a length approximately 2 -fold that of the somatic cilia. The oral ciliation was inconspicuous in a live state and was located at the central part of the anterior ventral surface. The ciliate contained a single translucent contractile vacuole located near the posterior pole (Figs $1 b$ \& 2a).

\section{Silver impregnation and SEM observation}

The morphometric characteristics of the specimens stained using silver impregnation are given in Table 1. The body was generally elongated with a rounded posterior and bluntly pointed anterior end. The ciliate was variable in size, ranging from 30 to $45 \mu \mathrm{m}(\mathrm{n}=20)$ in length and from 10 to $20 \mu \mathrm{m}(\mathrm{n}=20)$ in width. The ciliary meridians varied in number from 9 to 14 ( $\mathrm{n}=20$ ). The bipolar kineties were more or less evenly spaced except in the first and last ones, which were located to the right and left of the buccal cavity (Fig. 2b). All kineties, except for kinety 11, which ended just in front of membranelle 1 (M1), joined the circular fibril, at the anterior end and posteriorly joined the posterior circular fibril, which opened between longitudinal kineties 1 and 10 (Fig. 2b). An inconspicuous scutica

Fig. 1. Scuticociliates infecting Paralichthyus olivaceus. (a) Scuticociliates (arrows) massively invading the severely necrotized dermal layer. Silver impregnation, $\times 50$. (b) Live ciliate showing cadual cilium (CC) and contractile vacuole (CV), $\times 400$. (c) Silverimpregnated ciliate showing stomatogenetic stages representing scutico-filed (arrow), $\times 400$. (d) Silver-impregnated ciliate showing the meridionl arrangement of the ciliary row and cytoproct (arrow), $\times 400$. (e) A Giemsa-stained ciliate showing macronucleus (MA) and micronucleus (MI) $\times 1000 .(\mathrm{f}, \mathrm{g})$ Photomicrograph of scanning electron microscopy of cultured ciliates. Scale bar $=2 \mu \mathrm{m}$. (f) Ventro-posterior area detail. The contractile vacuole pore (CVP) is located between the kineties 1 and 2. CC: caudal cilium; SOC: somatic cilia. (g) Oral infraciliature detail. P: paroral membrane; M1: Membranelle 1; M2: Membranelle 2; M3: Membranelle 3, CY: cytostome 


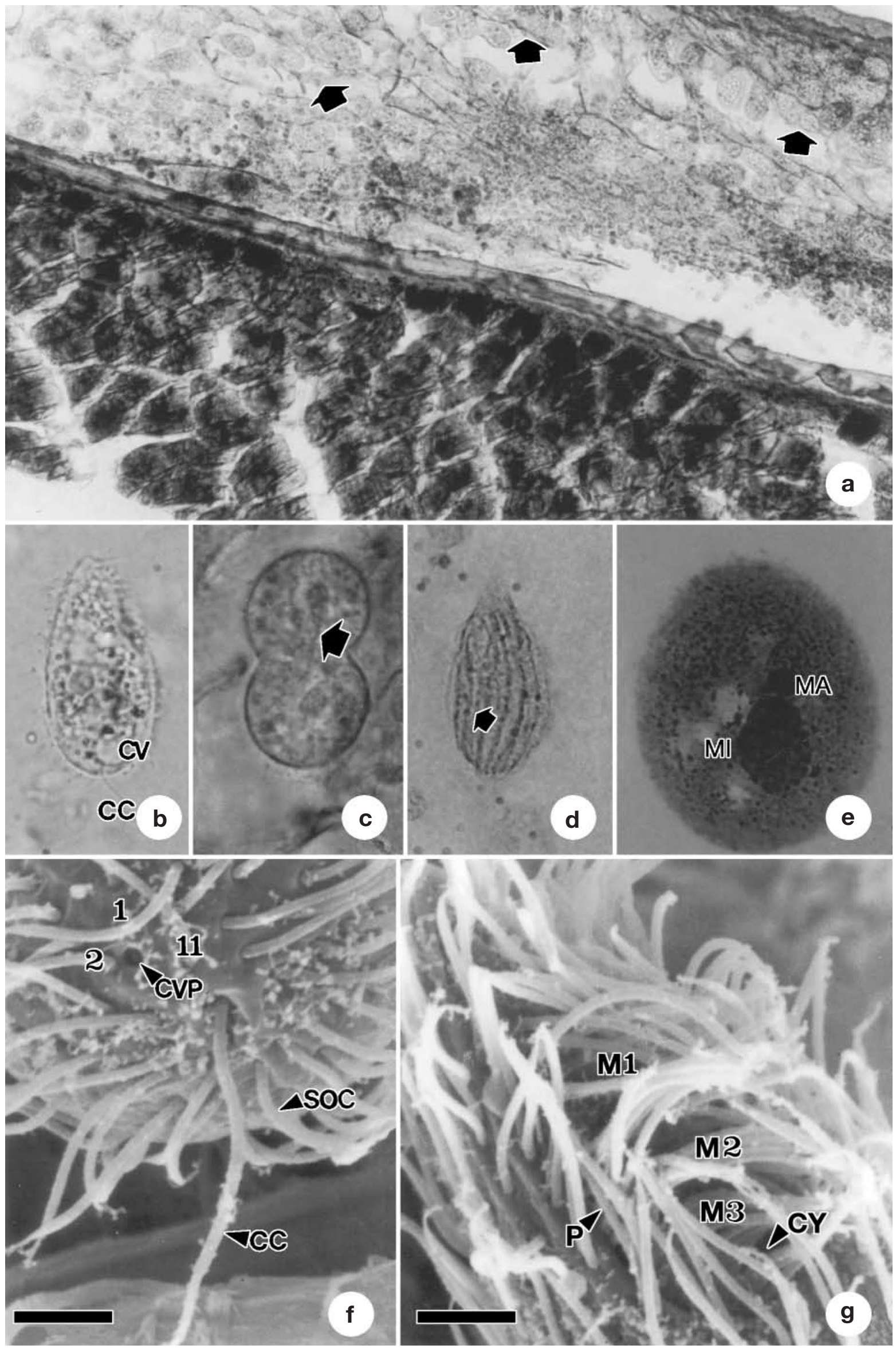



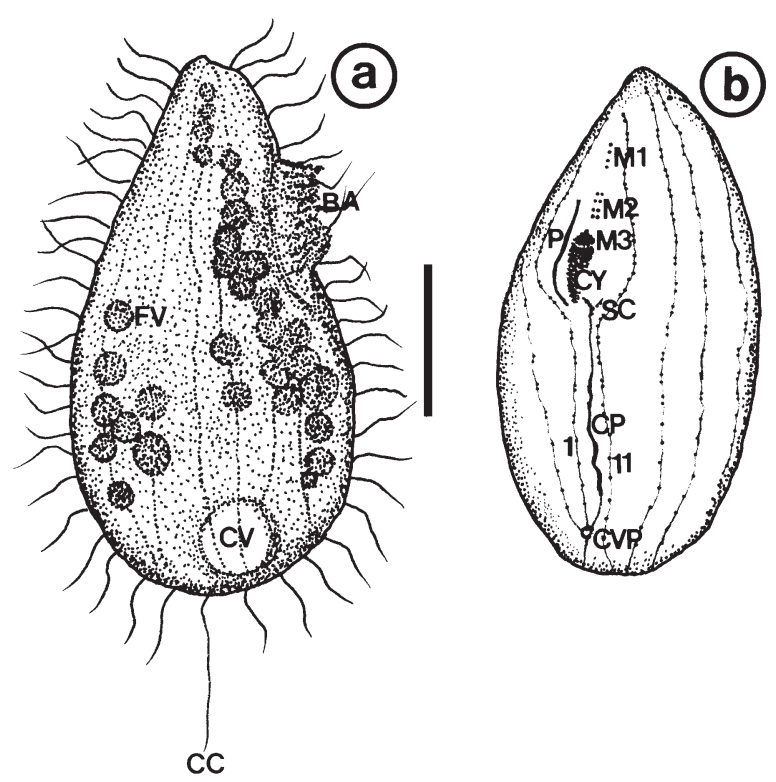

was located underneath the cytostomal area, usually with a V-shaped (hook-like) beginning (Fig. 2b). The elongate, shallow buccal cavity, possessed a tetrahymenal buccal apparatus and averaged $16.2 \mu \mathrm{m}$ (13 to $20 \mu \mathrm{m}, \mathrm{n}=10$ ) in length (Fig. 2b). The paroral membrane (P) was found on the right side of the buccal cavity and averaged $7.4 \mu \mathrm{m}(7$ to $8 \mu \mathrm{m}, \mathrm{n}=10)$ in length. It began near the posterior end of the buccal cavity and terminated at the middle membranelle 2 (M2). The anterior portion of the $\mathrm{P}$ was almost straight but the posterior portion was curved around the cytostomal area (Fig. 1g). The M1 was located in the anterior portion of the buccal cavity and averaged $2.5 \mu \mathrm{m}$

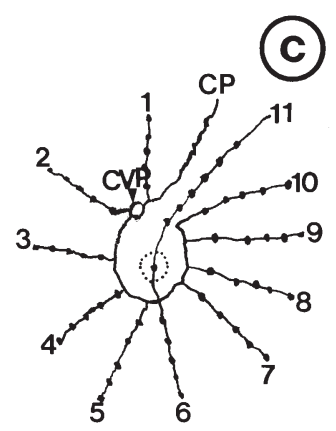

Fig. 2. Diagram of scuticoliate belonging to the parasitic form Uronema marinum recovered from brain of cultured olive flounder Paralichthyus olivaceus. Scale bar $=10 \mu \mathrm{m}$. (a) Right lateral view of live specimen. (b) Ventral view of silver-impregnated specimen. (c) Posterior polar view of silver-impregnated specimen. BA: buccal apparatus; FV: food vacuole; CV: contractile vacuole; CC: cadual cilium. P: paroral membrane; M1: membranelle one; M2: membranelle 2; M3: membranelle 3; CY: cytostome; SC: scutica; CP: cytoproct; CVP: contractile vacuole pore. 1-11: bipolar kinetics

( 2 to $3 \mu \mathrm{m}, \mathrm{n}=10$ ) in length. The M2 averaged $2.4 \mu \mathrm{m}$ ( 2 to $2.5 \mu \mathrm{m}, \mathrm{n}=10$ ) in length and appeared irregularly rectangular in shape. Membranelle 3 (M3) averaged $1.3 \mu \mathrm{m}(1$ to $1.6 \mu \mathrm{m}, \mathrm{n}=10)$ in length and was located above the cytostomal area. The cytostome appeared to be irregular in shape, occupying a large portion of the cytostomal area. The cytoproct was located between the first and the last kineties in the posterior half of the cell and appeared as a long, irregular line (Figs 1d \& $2 \mathrm{~b}, \mathrm{c})$. Nuclei staining with May-Giemsa solutions revealed the presence of a large spherical macronucleus and a small micronucleus located above the anterior to middle portion of the cell (Fig. 1e).

Table 1. Morphometric characteristics of Uronema marinum from the present study and literature

\begin{tabular}{|c|c|c|c|}
\hline Character & Thompson (1963) & Cheung et al. (1980) & Present study \\
\hline Source or host & Salt water & Marine fish & Olive flounder \\
\hline \multicolumn{4}{|l|}{ Body dimension $(\mu \mathrm{m})$} \\
\hline Length & 33.1 & $34.1(32-38)$ & $34.4(30-45)$ \\
\hline Width & 17.4 & $15.8(13-20)$ & $16.4(10-20)$ \\
\hline \multicolumn{4}{|l|}{ Nuclei diameter $(\mu \mathrm{m})$} \\
\hline Macronucleus & 5 & 5 & $7.7(5-11)$ \\
\hline \multicolumn{4}{|l|}{ Somatic ciliature } \\
\hline Number of kineties & $15(13-16)$ & $10-13$ & $11.4(9-14)$ \\
\hline Length of cilia $(\mu \mathrm{m})$ & - & - & $5.5(4.5-7)$ \\
\hline Length of caudal cilium $(\mu \mathrm{m})$ & - & - & $11(9-14)$ \\
\hline \multicolumn{4}{|l|}{ Oral ciliature $(\mu \mathrm{m})$} \\
\hline Length of buccal cavity & 16.3 & $18.9 \pm 3$ & $16.2(13-20)$ \\
\hline Length of undulating membrane & 7.5 & $6.2 \pm 1.8$ & $7.4(6.5-8)$ \\
\hline Length of first membranelle & 2.8 & $2.5 \pm 0.5$ & $2.5(2-3)$ \\
\hline Length of second membranelle & 2.5 & 2 & $2.4(2-2.5)$ \\
\hline Length of third membranelle & 1.3 & 1.2 & $1.3(1-1.6)$ \\
\hline
\end{tabular}




\section{Morphometry of the ciliates}

The clinical isolates varied morphometrically with different affected parts of the host, while the cultured ciliates did not show variations in morphometry. The clinical isolates from the brain, which averaged $43.3 \pm$ $4.28 \mu \mathrm{m}$ (30 to $60 \mu \mathrm{m}, \mathrm{n}=20$ ) in body length, were significantly larger $(\mathrm{p}<0.05)$ than those from the skin, which averaged $34.9 \pm 2.36 \mu \mathrm{m}$ (30 to $40 \mu \mathrm{m}, \mathrm{n}=20$ ) in body length. However, these 2 ciliates did not show any significant difference in morphometry under cultured condition (Fig. 3).

\section{Effect of temperature on the ciliates}

No effects on propagation of the ciliate were observed at temperatures from 6 to $30^{\circ} \mathrm{C}$ (Table 2). At $36^{\circ} \mathrm{C}$, cell division was not observed within $2 \mathrm{~d}$, and thereafter the ciliate swelled and lysed (data not shown). At temperatures from 6 to $30^{\circ} \mathrm{C}$, maximum ciliate densities were almost the same $\left(2.2-2.5 \times 10^{4}\right.$ cell $\mathrm{ml}^{-1}$ ) and achieved maximum densities proportional to the number of days of exposure.

\section{Effect of salinity on the ciliates}

No effects on the motility of the ciliates were observed at salinities from 25 to 35 ppt (Table 3 ). This result suggests that the optimum salinity for ciliates ranged from 25 to $35 \mathrm{ppt}$. At both at 5 and at $40 \mathrm{ppt}$, the ciliate stopped the ciliary beat within $6 \mathrm{~h}$, then the shape of body became rounded and the cell was lysed.

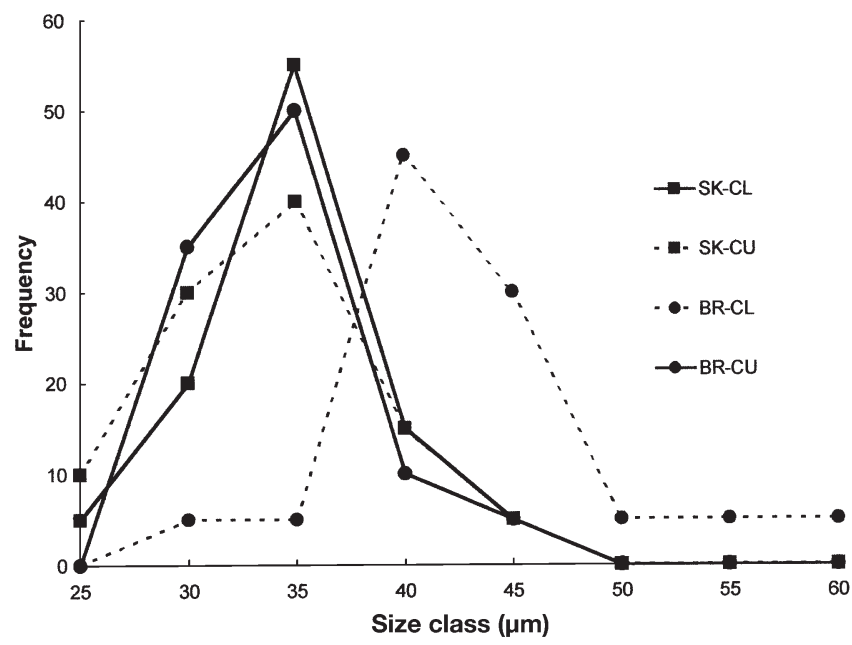

Fig. 3. Frequency distribution of body length of clinical (CL) and cultured (CU) scuticociliates from the skin (SK) and brain (BR) recovered from cultured olive flounder Paralichthyus olivaceus. Each value is the mean $(\mathrm{n}=20)$ of duplicated measurements
Table 2. Effects of temperature on propagation of scuticociliates recovered from cultured olive flounder Paralichthyus olivaceus. Each value represents the mean of 3 replicate experiments. +: initial cell density $\left(<10^{2}\right.$ cell ml$\left.l^{-1}\right) ;++$ : moderate cell density $\left(10^{2}-10^{4}\right.$ cell ml $\left.{ }^{-1}\right)$, +++: high cell density $\left(>10^{4}\right.$ cell ml $\left.{ }^{-1}\right)$

\begin{tabular}{|lcccccccccc|}
\hline $\begin{array}{l}\text { Temperature } \\
\left({ }^{\circ} \mathrm{C}\right)\end{array}$ & 0 & 1 & 3 & 5 & 7 & 9 & 11 & 13 & 15 \\
\hline 30 & + & ++ & +++ & +++ & +++ & ++ & ++ & ++ & ++ \\
24 & + & ++ & +++ & +++ & +++ & +++ & +++ & ++ & ++ \\
18 & + & ++ & ++ & +++ & +++ & +++ & ++ & ++ & ++ \\
16 & + & + & ++ & ++ & +++ & +++ & +++ & ++ & ++ \\
12 & + & + & + & ++ & ++ & ++ & ++ & +++ & ++ \\
6 & + & + & + & + & + & ++ & ++ & ++ & +++ \\
\hline
\end{tabular}

\section{DICUSSION}

Scuticociliates, previously regarded as exclusively free-living ciliates, have recently been recognized as a serious pathogen (Thompson 1963, Cheung et al. 1980, Bassleer 1983, Lom \& Dykova 1992). Some species present in marine fish have been well studied (Cheung et al. 1980, Dragesco et al. 1995, Munday et al. 1997), while other ciliates associated with disease outbreaks have not yet been fully identified (Yoshinaga \& Nakazoe 1993, Dykova \& Figueras 1994). Dykova \& Figueras (1994) have assigned tentatively the scuticociliates isolated from cultured turbot to either Uronema marinum or Miamiensis avidus. The present ciliate in olive flounder, readily identified as a scuticociliate by a distinctive scutica located below the oral ciliary field, belongs to the suborder Philasterina because its paroral membrane is shorter than the other oral structures (Corliss 1979). Of the 12 constituent families, its ciliate belongs to the family Uronematidae because its buccal apparatus consisted of an elongate shallow buccal cavity and paroral membrane and 3

Table 3. Effects of salinity on motility of scuticociliates recovered from olive flounder Paralichthyus olivaceus at $18^{\circ} \mathrm{C}$. Each value represents the mean of 3 replicate experiments. +++: no effect; ++: decreased motility; +: motility loss, -: cell lysis

\begin{tabular}{|lccccccccc|}
\hline $\begin{array}{l}\text { Salinities } \\
\text { (ppt) }\end{array}$ & 0 & 1 & 6 & 12 & 24 & 48 & 72 & 96 \\
\hline 40 & +++ & +++ & - & - & - & - & - & - \\
35 & +++ & +++ & +++ & +++ & +++ & +++ & +++ & +++ \\
30 & +++ & +++ & +++ & +++ & +++ & +++ & +++ & +++ \\
25 & +++ & +++ & +++ & +++ & +++ & +++ & +++ & +++ \\
20 & +++ & ++ & ++ & +++ & +++ & +++ & +++ & +++ \\
15 & +++ & + & ++ & ++ & +++ & +++ & +++ & +++ \\
10 & +++ & + & + & + & ++ & ++ & ++ & ++ \\
5 & +++ & + & - & - & - & - & - & - \\
\hline
\end{tabular}


membranelles were aligned with the long axis of the body (Thompson 1963). The ciliate is assigned to the genus Uronema on the basis of the shape of its buccal cavity, the fact that M1 consists of a single row of granules, and the location of the cytostome (Thompson 1963, Cheung et al. 1980, Small \& Lynn 1985). There are only 2 other genera, Philasterides and Miamiensis, with a similar buccal apparatus. However, the buccal cavity of both Philasterides and Miamiensis is narrower or wider compared to that of Uronema (Mugard 1949, Thompson \& Moewus 1964). The present ciliate had morphological characteristics, except for kinety number, very similar to those of the free-living marine form $U$. marinum Dujardin, which has been redescribed by Thompson (1963). Cheung et al. (1980) have described a parasitic form of $U$. marinum which had the ability to invade fish and had a lower kinety number than that of $U$. marinum. Lom \& Dykova (1992) considered $U$. marinum, which has 10 to 13 longitudinal kineties, to be facultative parasites of marine fish. The present ciliate is therefore identified as the parasitic phase of $U$. marinum on the basis of the following features: (1) a buccal structure identical to that of the free-living marine form of $U$. marinum, and (2) the ability to invade fish tissue.

The pathology of scuticociliate-infected flounder is very similar to that reported by Cheung et al. (1980) in marine fish infected Uronema marinum and that reported by Dykova \& Figueras (1994) in turbot infected with a histophagous ciliate. The present ciliate is highly invasive and destructive to host tissue, ingesting host cells or tissue debris. It is noted that the present ciliate may be a histophagous species, acting on a serious pathogen in cultured flounder.

In the present study, a distinct morphometry of scuticociliates occurred in the clinical isolates examined. The body length of skin isolates was significantly smaller than that of brain isolates. However, the 2 groups showed a similar size under culture conditions. The data suggest that the food source affects the morphometry of the ciliate. This suggestion corresponds well with reports by Fenchel (1990), who demonstrated morphological changes attributed to starvation and refeeding in Uronema marinum.

It is noted that the present ciliate could propagate in a wide range of temperatures $\left(6\right.$ to $\left.30^{\circ} \mathrm{C}\right)$ and salinities (10 to $35 \mathrm{ppt}$ ). The biological characteristics of the present ciliate are very similar to those reported by some other authors (Hamilton \& Preslan 1969, Parker 1976). They observed the same features in the in vitro growth response of Uronema marinum. It was noted that in vitro $U$. nigricans was marginal at temperatures of 10 to $25^{\circ} \mathrm{C}$ at salinities between 15 and 35 ppt (Crosbie \& Munday 1999). Similarly, Cheung et al. (1980) noted occurrences of a wide fluctuation of both salinity
(21 to $31 \mathrm{ppt}$ ) and temperatures ( 8 to $28^{\circ} \mathrm{C}$ ) during an epizootic caused by $U$. marinum at a marine fish aquarium.

In conclusion, the present study shows that the scuticociliate isolated from cultured olive flounder is a parasitic phase of Uronema marinum, a histophagous species, and that the food source affects the morphometry of the ciliates. The fact that the ciliate was found in a wide range of temperatures and salinities suggests that it may be difficult to control scuticociliatosis of cultured olive flounder by improving environmental factors such as temperatures or salinities.

\section{LITERATURE CITED}

Bassleer G (1983) Uronema marinum, a new and common parasite on tropical saltwater fishes. Freshw Mar Aquarium 6:78-81

Cheung PJ, Rigrelli RF, Ruggieri GD (1980) Studies on the morphology of Uronema marinum Dujardin (Ciliatea: Uronematidae) with a description of the histopathology of the infection in marine fishes. J Fish Dis 3:295-303

Corliss JO (1979) The ciliated protozoa. Pergamon Press, Oxford

Crosbie PBB, Munday BL (1999) Environmental factors and chemical agents affecting the growth of the pathogenic marine ciliate Uronema nigricans. Dis Aquat Org 36: $213-219$

Dragesco A, Dragesco J, Coste F, Gasc C, Romestand B, Raymond JC, Bouxi G (1995) Philasterides dicentrarchi n. sp., (Ciliophora, Scuticociliatida), a histophagous opportunistic parasite of Dicentrarchus labrax (Linnaeus, 1758), a reared marine fish. Eur J Protistol 31:327-340

Dykova I, Figueras A (1994) Histopathological changes in turbot Scophthalmus maximus due to a histophgous ciliate. Dis Aquat Org 18:5-9

Fenchel T (1990) Adaptive significance of polymorphic life cycle in protozoa: responses to starvation and refeeding in two species of marine ciliates. J Exp Mar Biol Ecol 136: $159-177$

Foissner W (1991) Basic light and scanning electron microscopic methods for taxonomic studies of ciliated protozoa. Eur J Protistol 27:313-330

Hamilton RD, Preslan JE (1969) Cultural characteristics of a pelagic marine hymenostome ciliate, Uronema sp. J Exp Mar Biol Ecol 4:90-99

Klein BM (1958) The dry silver method and its proper use. J Protzool 5:99-103

Lom J, Dykova I (1992) Protozoan parasites of fishes. Elsevier Science Publishers BV, Amsterdam

Mugard H (1949) Contribution a l'etude des infusoires hymenostomes histiophages. Ann Sci Natl Zool (Ser 11) 10:171-268

Munday BL, O'Donoghue PJ, Watts M, Rough K, Hawkesford K (1997) Fatal encephalitis due to the scuticociliate Uronema nigricans in sea-caged, southern bluefin tuna Thunnus maccoyii. Dis Aquat Org 30:17-25

Ototake M, Matsusato T (1986) Notes on scuticociliata infection of cultured juvenile flounder, Paralichthys olivaceus. Bull Natl Res Inst Aquacult 9:65-68 (in Japanese)

Parker JG (1976) Cultural characteristics of the marine ciliated protozoan, Uronema marinum Dujardin. J Exp Mar Biol Ecol 24:213-226 
Small EB, Lynn DH (1985) Phylum Ciliophorea Doflein, 1901. In: Lee JJ, Hutner SH, Bovee EC (eds) An illustrated guide to the protozoa. Society of Protozoologists, Lawrence, Kansas, p 393-575

Thompson JC (1963) A redescription of Uronema marinum, and a proposed new family Uronematidae. VA J Sci 15: $80-87$

Thompson JC, Moewus L (1964) Miamiensis avidus n.g., n. sp., a marine faculative parasite in the ciliate order

Editorial responsibility: Wolfgang Körting,

Hannover, Germany
Hymenostomatida. J Protozool 11:378-381

Yoshinaga T, Nakazoe J (1993) Isolation and in vitro cultivation of an unidentified ciliate causing scuticociliatosis in Japanese flounder(Paralichthys olivaceus). Fish Pathol 28: 131-134

Yoshinaga T, Nakazoe J (1997) Effects of light and rotation culture on the in vitro growth of ciliate causing the scuticociliatosis of Japanese flounder. Fish Pathol 32: $227-228$

Submitted: October 4, 2000; Accepted: April 4, 2001

Proofs received from author(s): October 12, 2001 